\title{
TWO-DIMENSIONAL AND THREE-DIMENSIONAL MODELS USED FOR TEACHING HUMAN Evolution IN SECondary SCHOOLS. LEARNING PROFICIENCY ASSESSMENT. A Case STUdy
}

\section{Ulisses Dardon ${ }^{*}$, Viviane Vieira ${ }^{2}$, Stella Barbara Serodio Prestes ${ }^{3}$, Thaís de Castro Cunha Parméra ${ }^{4}$, LeONardo}

\section{COTTS $^{5}$ AND LÍLIAN PAgLARELLI BERgQVIST ${ }^{6}$}

1 Programa de Pós-Graduação em Análises de Bacias e Faixas Móveis. Faculdade de Geologia, Universidade do Estado do Rio de Janeiro (UERJ), Av. São Francisco Xavier, 524, sala 4037F, Maracanã, CEP. 20550-013, Rio de Janeiro, RJ, Brazil. dardonnn@gmail.com

2 Programa de Pós-graduação em Educação em Ciências e Saúde, Núcleo de Tecnologia Educacional para a Saúde, Centro de Ciências da Saúde, Bloco A - Sala 28, Universidade Federal do Rio de Janeiro (UFRJ), Ilha do Fundão, Cidade Universitária, 21941-902, Rio de Janeiro, Brazil. vivianevieira.biologia@gmail.com

3 Programa de Pós-graduação em Educação e Divulgação Científica do Instituto Federal do Rio de Janeiro (IFRJ), Campus Mesquita, Rua Paulo I, s/n, Praça João Luiz do Nascimento, Centro, Mesquita, Cep: 26551-240, Rio de Janeiro, RJ, Brazil. telababi@gmail.com

4 Programa de Pós-graduação em Ecologia e Evolução, Universidade do Estado do Rio de Janeiro (UERJ), Av. São Francisco Xavier, 524, PHLC $2^{\circ}$ andar, sala 224, Maracanã, CEP. 20550-013, Rio de Janeiro, RJ, Brazil. thaisparmera@yahoo.com.br

5 Programa de Pós-graduação em Biodiversidade e Biologia Evolutiva, Universidade Federal do Rio de Janeiro (UFRJ), Ilha do Fundão, Cidade Universitária, CEP. 21941-902. Rio de Janeiro, Brazil. cotts.vert@gmail.com

6 Universidade Federal do Rio de Janeiro (UFRJ), Departamento de Geologia, Av. Athos da Silveira Ramos, 274, Ilha do Fundão, Cidade Universitária, CEP 21941-916, Rio de Janeiro RJ, Brazil. bergqvist@geologia.ufrj.br

*CORRESPONDING AUTHOR, dardonnn@gmail.com

Received on 23 May 2016

Received in revised form on 20 June 2016

Accepted on 24 June 2016

Editor:

Sérgio Bergamaschi, Universidade do Estado do Rio de Janeiro, Brazil
Citation:

Dardon, U., Vieira, V., Prestes, S.B.S., Parméra, T.C.C., Cotts, L., Bergqvist, L.P., 2016. Two-dimensional and three-dimensional models used for teaching Human Evolution in Secondary Schools. Learning proficiency assessment. A Case Stud. Journal of Sedimentary Environments, 1(2): 279-291.

\section{Abstract}

The evolution of the human species is a topic of extreme importance reported in the "Parâmetros Curriculares Nacionais do Ensino Médio - PCNEM" (National Curriculum Standards of Secondary Education), although it is not often taught as part of basic education. This work presents the results of an experimental work performed with 31 students of a religious high school of State of Rio de Janeiro. Learning proficiency was assessed by using twodimensional (2D) and three-dimensional (3D) illustration techniques of hominids skulls and a Pongidae for teaching Human Evolution. The teaching-learning process using these methodologies was more effective with the application of three-dimensional (3D) illustration techniques. The group of students that used 3D illustrations were able to observe similarities and differences between the presented taxonomic models, and formulate hypotheses about their palaeobiology more consistently than the students that used 2D models. Results of this work indicate that the use of threedimensional techniques (3D) provides an excellent support to teaching-learning process in basic education, captivating and stimulating new interests of students during the educational process.

Keywords: Science Education. Human evolution. Didactic resources. 2D/3D Models. Paleobiology. Computer. 


\section{Introduction}

The evolution of the human species is one of the most important topics of evolutionary theory, because it explains the common ancestry between species due to genetic modifications marked by natural selection, environmental influence, culture and migration (Penny and Poole, 1999; Ayala, 2007). This theme is very relevant, since it tries to explain the wide range of different human characteristics that are distinct from other living beings.

A proper understanding of the emergence and evolution of life in its various forms of demonstrations and demands provides an understanding of the geological and environmental conditions prevailing in the primitive world, allowing to develop educational projects that seek to test hypotheses about the evolution of species, including humans (Brasil, 2000).

In accordance with the PCNEM the approach and learning of these Biology issues is inseparable from the other sciences (Brasil, 2000).

According to the "Orientações Complementares aos Parâmetros Curriculares Nacionais do Ensino Médio" (Complementary Guidelines to the National Curriculum Parameters of High School), students should understand vital processes at different scales of time and become familiar with the basic mechanisms that allowed the evolution of life and of the human being in particular (Brasil, 2002).

The document "Currículo Mínimo" (Minimum Curriculum) of State of Rio de Janeiro, proposes that issues related to human evolution should be taught in high school, during the first grade, from the end of the second quarter and during the entire third quarter (Rio de Janeiro, 2012).

Despite these recommendations, the teaching of this subject has found obstacles related to specific concepts of evolutionary theory (such as adaptation and evolution), school socioeconomic context (such as lack of infrastructure and lack of teachers) and cultural characteristics of students including religious beliefs (Castro and Augusto, 2009; Silva et al., 2009; Pazza et al., 2010; Oliveira and Bizzo, 2011; Oliveira et al., 2011; Roberto and Bonotto, 2012; Vieira and Falcão., 2012).

According to Moura and Silva-Santana (2012), some researches have shown that teachers have Lamarckian conceptions about human evolution and evolutionary theory, which are taught in the third year of high school.
According to these authors, the investigated teachers declared that there are in the schools lack of teaching materials and insufficient time for teaching that subjects (Tidon and Vieira, 2009; Mottola, 2012; Moura and SilvaSantana, 2012; Roberto and Bonotto, 2012). Vieira and Falcão (2014) observed that in a religious school the teaching of the evolutionary theory is limited and teachers present the evolution in a context of devaluation of scientific explanations.

Several studies have shown that 3D technology provides more motivating and engaging environment for the practice of educational tasks than the 2D one (Santos et al., 2003; Seabra and Santos, 2004; 'Toti et al., 2008).

According to Bento and Gonçalves (2011), navigation in a three dimensional environment is easy to handle and so young people do not feel great difficulty in dominating it.

In paleontology, the analysis of 3D models can facilitate the observation of morphological structures of the fossil skeletons improving the educational process (Sutton et al., 2001).

The use of the 3D technique enables the understanding of the spatial structure of the scanned material, allows to analyze more precisely the functioning of the anatomical parts of the organisms (Wilhite, 2003).

This work is the result of a survey that aimed to compare the learning process of the human evolution theme using two different methods: 3D technology and traditional teaching resources based on 2D models, in order to verify which method allowed to obtain better results of learning. It also had the following objectives:

1) To observe and analyze the similarities and differences between the skulls of the following species: Homo sapiens sapiens, Homo sapiens neanderthalensis, Homo erectus, Australopithecus afarensis and Pan troglodytes.

2) To observe the structures - jaws, sagittal crest, teeth, foramen magnum, prominence of the face, observation of facial features in side view of skull, supraorbital arch and nasal passages and to show differences between the skulls of the mentioned species.

3) To motivate students to formulate hypotheses related to the form of communication, food and human evolution, based on the observation and analysis of the characteristics of anatomical structures. 


\section{Material and methods}

In a first stage, the employed didactic strategy to achieve mentioned objectives (in the previous section) consisted of three procedures with total duration of 45 minutes:

I. Lecture showing 2D and 3D models of the skulls of the following species: Homo sapiens sapiens and Homo erectus; Homo erectus and Australopithecus afarensis; Australopithecus afarensis and Pan troglodytes; Homo erectus and Homo sapiens neanderthalensis.

II. Skulls comparison: students observe the differences and similarities between the structures of hominids and a Pongidae.

III. Hypothesizing about differences and similarities of the skulls. It is important in this activity, motivate students to observe and analyze such structures and then propose to them the formulation of hypotheses, questions or doubts.

All the questions or concerns presented by the students were appreciated and considered as explanatory hypotheses and then discussed with the monitor (two graduate students in biological sciences and a $\mathrm{PhD}$ student in Science Education and Health). Then students separated into two groups (with 2D and 3D models), answered to a questionnaire for approximately 45 minutes.

Students of the third year of high school, involved in this research, attended an Adventist school, located in a church of the same name. The school has good physical structure, with ventilation (air-conditioned) and lighting classrooms, whiteboards, comfortable desks, modern pedagogical teaching equipment (portable projectors and computers), library, staff room, auditoriums for lectures and meetings with parents, pedagogic coordination and support of a psychologist.

This school offers education from kindergarten to the pre-university. The curriculum of this school for high school is comprised of the regular disciplines (Portuguese, Mathematics, Biology, Physics, Chemistry, History, Geography, Literature, English and Spanish). The curriculum also includes the Religion study.

The political pedagogical project of this school includes teaching of all aspects of the evolutionary theory (basic concepts, evidence of evolution, evolutionary theories of Lamarck and Darwin, evolutionary mechanisms and modern aspects of genetics related to evolution. However, teachers are oriented to teach these issues in articulation with the Christian precepts.

It is important to note that this research was approved by the school administration, by the teaching college of Biology and by the Comissão Nacional de Ética em Pesquisa-
CONEP (National Research Ethics Commission of the UFRJ, documented by the number 052907/2013).

The activities took place in the "Museu de Geodiversidade" (Museum of Geodiversity) and in the "Centro de Estudos de Mudanças Ambientais" (CEMA; Research Centre of Environmental Changes), both in the "Instituto de Geociências" (Geosciences Institute), of "Centro de Ciências da Matemática e da Natureza" (Sciences Center of Mathematical and Nature) of UFRJ.

To perform the activity with the $2 \mathrm{D}$ teaching resource, the module of the "Museu de Geodiversidade" (Geodiversity Museum) with the exhibition of Brazilian dinosaurs was chosen. This module provides images via a pen drive and a television equipment.

To work with the 3D educational resource, the space chosen was the CEMA, using a projector, laptop and the website http://www.nhm.ac.uk/nature-online/life/ humanorigins / modern-human-evolution/3d (Fig. 1) of the Natural History Museum in London, England. This page allows the observation and the evaluation of the similarities and differences of the structures of the skulls of hominids and a Pongidae.

In the activity using the $2 \mathrm{D}$ didactic recourses, images taken from the page http://www.nhm.ac.uk/natureonline/life/human-origins/modern-human-evolution/3dhominid-skulls/ were used, treated and exported with extension *.jpg (Figs. 2-6). On this website page, skulls can be moved and handled horizontally.

The 2D images were made from 3D models, taken from this site and processed in Adobe Photoshop. In this way, students were able to use the same skulls, with a difference of three-dimensional and two-dimensional view.

Thirty-one students participated in this study in the refereed school: a group of 15 students made the proposal with the 3D teaching tool, and the other group of 16 students, conducted the activity with $2 \mathrm{D}$ teaching resource.

The members of each team were randomly chosen. The two students' groups had no contact. The activity lasted approximately 1 hour and 30 minutes.

Students wore coats used clipboards and pens to make records of what they observed in the museum.

The approach of the content was carried out with 3 monitors that addressed topics related to evolutionary theory. Students analyzed the similarities and differences between each skull of the studied species. 


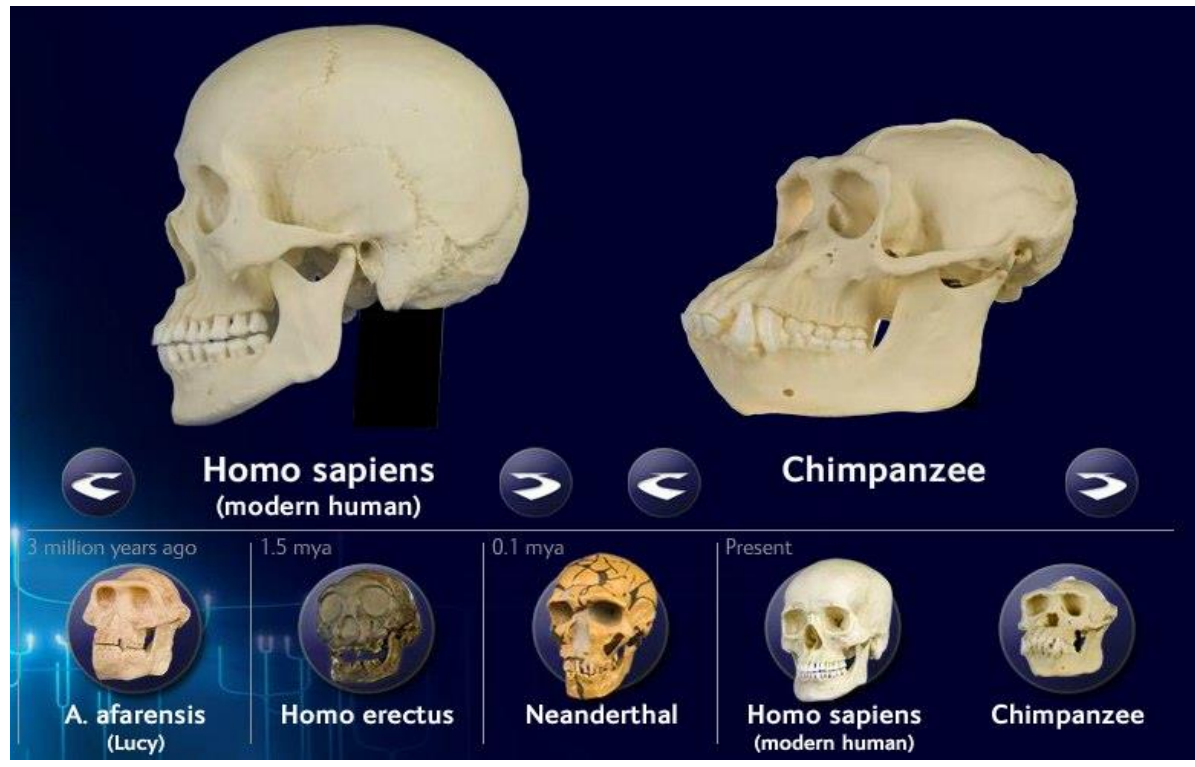

Fig. 1. 3D models giving a sense of visual immersion. Image taken from http://www.nhm.ac.uk/nature-online/life/humanorigins/modern-human-evolution/3d-hominid-skulls

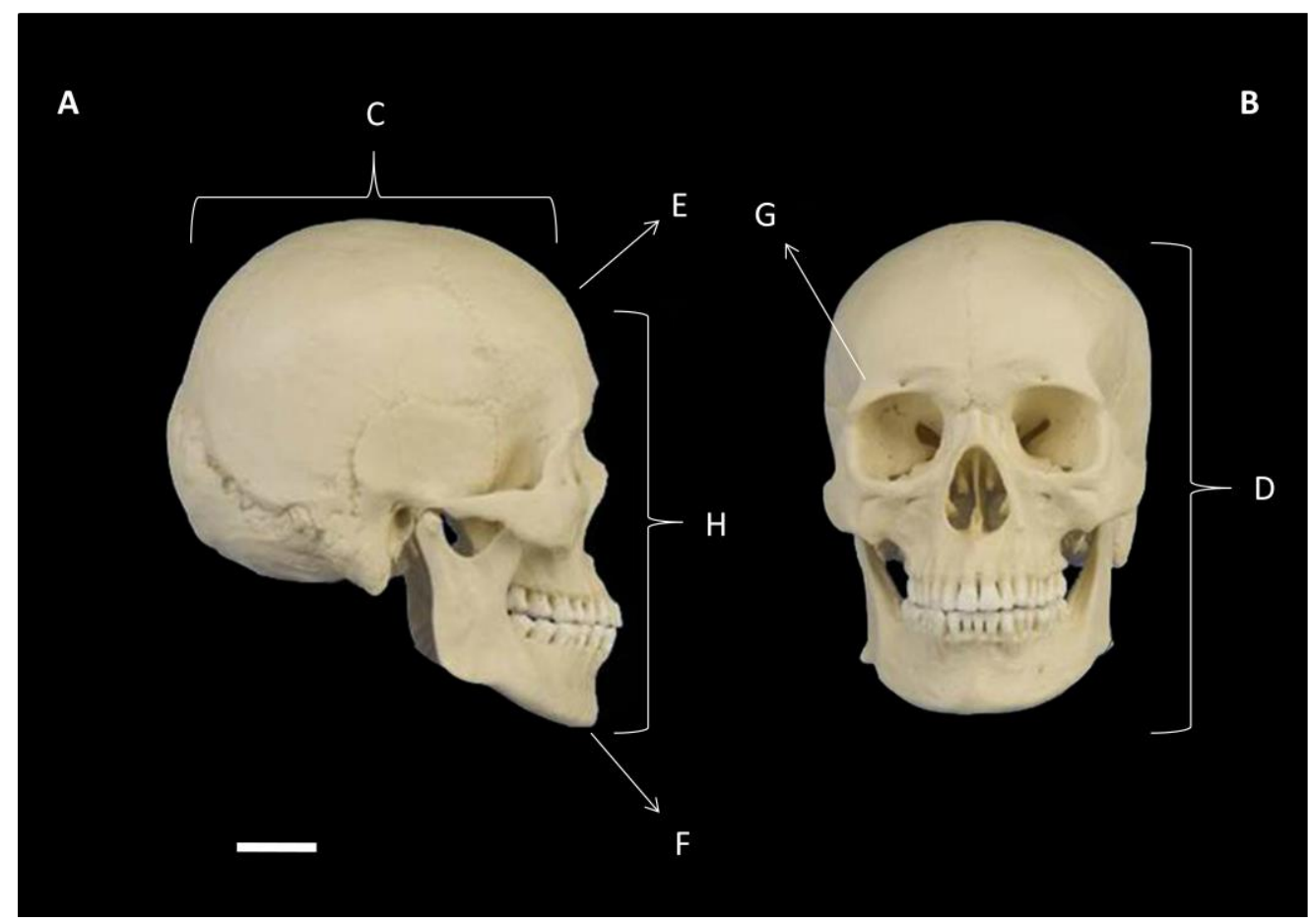

Fig. 2. Side (A) and front (B) view of the skull of Homo sapiens sapiens. C: Not elongated skull, D: High braincase, E: High frontal region, F: Presence of chin (Mental Protuberance), G: Supraciliary high and not prominent arcade and H: Sinuosity face no prominent. Scale Bar: $5 \mathrm{~cm}$. Modified from <http://www.nhm.ac.uk/nature-online/life/human-origins/modern-human-evolution/3d-hominid-skulls>. 
Data collection was performed by means of an anonymous individual questionnaire. This tool contained open questions related to the differences and similarities of hominid skulls (Homo sapiens sapiens, Homo erectus, Homo sapiens neanderthalensis, Australopithecus afarensis) and a Pan troglodytes. To analyze the perceptions and the learning process of students about human evolution, the concept of social representations of Serge Moscovici (Santos and Dias, 2015) was used. This concept, based on the integration of interpretations and answers, allows to evaluate what are the formulations that form a 'concept group' about a given information (Jodelet, 1990; Sêga, 2000).

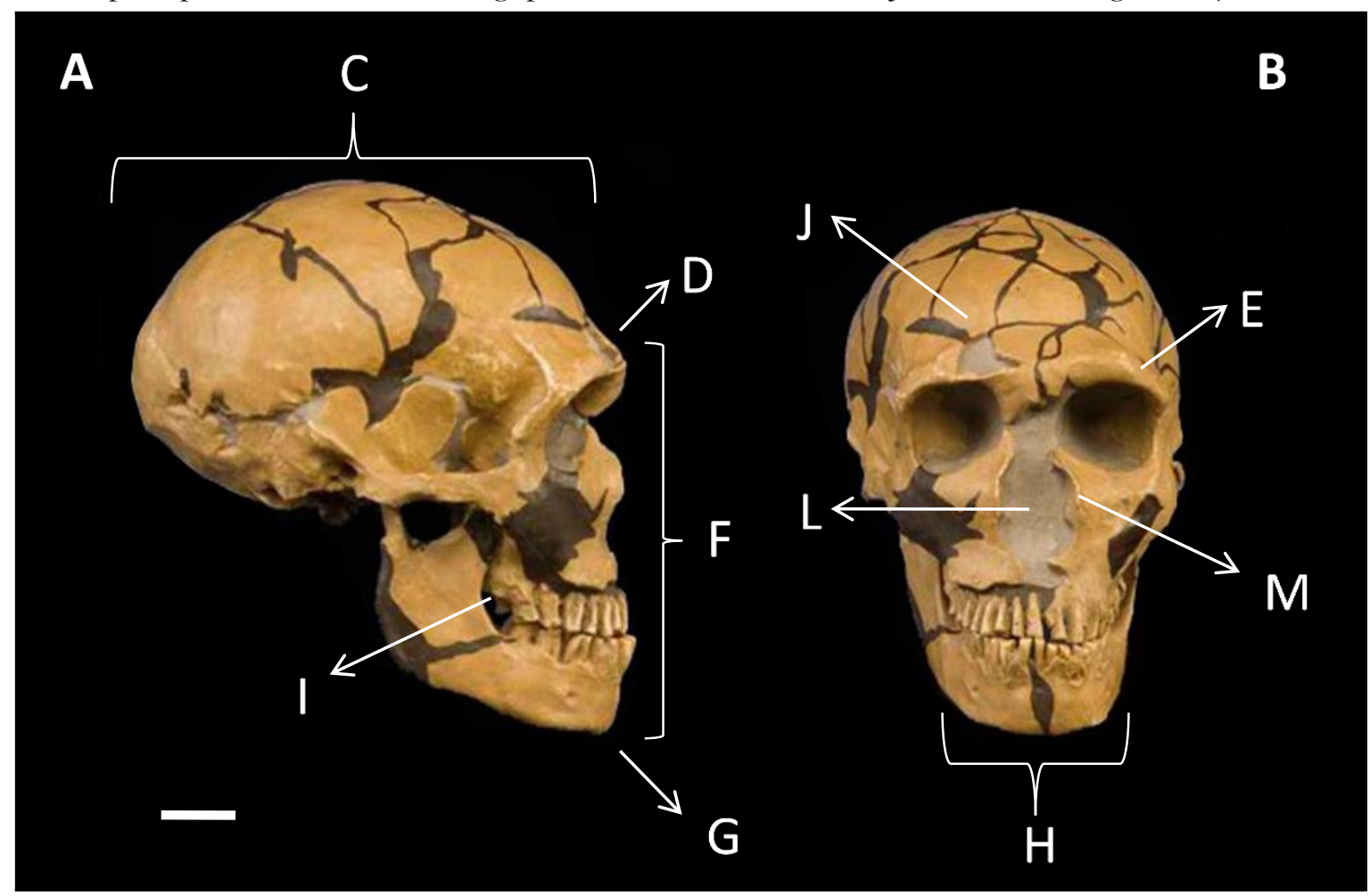

Fig. 3. Side (A) and front (B) view of the skull of Homo sapiens neanderthalensis. C: Skull large and elongated backward, D, E: Prominent supraorbital arcade, F: Sinuous face and low prominent, G, H, Absence of Mental Protuberance, I: Space between the curvature of the jaw with the last molars, J: Retreated frontal region, L: Broad nasal aperture and M: bony protuberances on the sides of the nasal aperture. Scale Bar $5 \mathrm{~cm}$. Modified from <http://www.nhm.ac.uk/nature-online/life/human-origins/modern-human-evolution/3d-hominidskulls $>$.

Students of each team create a network of relationships with each other aiming to design the best structure of new knowledge, which is influenced by the social relashionships and cognitive functioning organization of the team members (Sêga, 2000).

In this work, the social representations are used to analyze which were the visions, values and effects built by students after the activity about human evolution teaching. Such representations were analyzed by the technique of the Collective Subject Discourse (CSD) developed by Lefèvre and Lefèvre (2003).

This technique consists of write a single speech in the first person singular, through various statements (reporting
This technique is applied in opinion polls and and is used to review answers given to open questions, grouping the statements with similar sense of synthetic discourses written in the first person.

The CSD methodology consists of analyzing statements and other verbal materials by removing the central ideas from Expressions Key (EC).

From the central/anchors and correspondents EC ideas, one or more synthetic discourses of the collective subject are constructed (Godim and Fischer, 2009).

their assumptions and opinions) collected in a specific team and thus it can be used as a case study. It is a technique that 
allows the obtainment of quantitative data, since it allows to register the number of individuals that share the same central idea. It also provides qualitative data which can be converted

\section{Results}

Tables 1-3 synthesize the student responses given to three central ideas (CSD1-CSD3) related to the following questions: 1) "What are the differences of sinuous in the lateral profile of each skull?"; 2) "What kind of influence has developed this difference?"; 3) Do you think that Homo sapiens neanderthalensis could speak? Explain your answer.

The answers to those questions is based on the analysis of $2 \mathrm{D}$ or $3 \mathrm{D}$ educational resources that were provided to each working teams. These issues were selected because they are the most relevant in evaluating the development of hypotheses about human evolution in relation to anatomy, influence of the environment and culture (eg: communication). Thus they provide a greater chance of learning evaluation and formulation of hypothesis about human evolution. into numerical data. In this way, the CSD provides qualitative information which may have statistical applicability (Diniz et al., 2011).
Tables 1-3 record the answers to three key ideas (CSD1CSD3) and also summarize the discourse synthesis built by students from their answers. The number of concordant answers to each question was included in that tables.

\subsection{Results presented in Table 1}

In CSD1 and CSD2 of Table 1, the students observed and evaluated the similarities and differences, between the analysed skulls. In CSD3 of Table 1, students observed and analyzed the similarities between the skulls of $H$. sapiens and $H$. sapiens neanderthalensis and also distinguished the differences between the skulls of $H$. erectus and $H$. sapiens neaderthalensis.

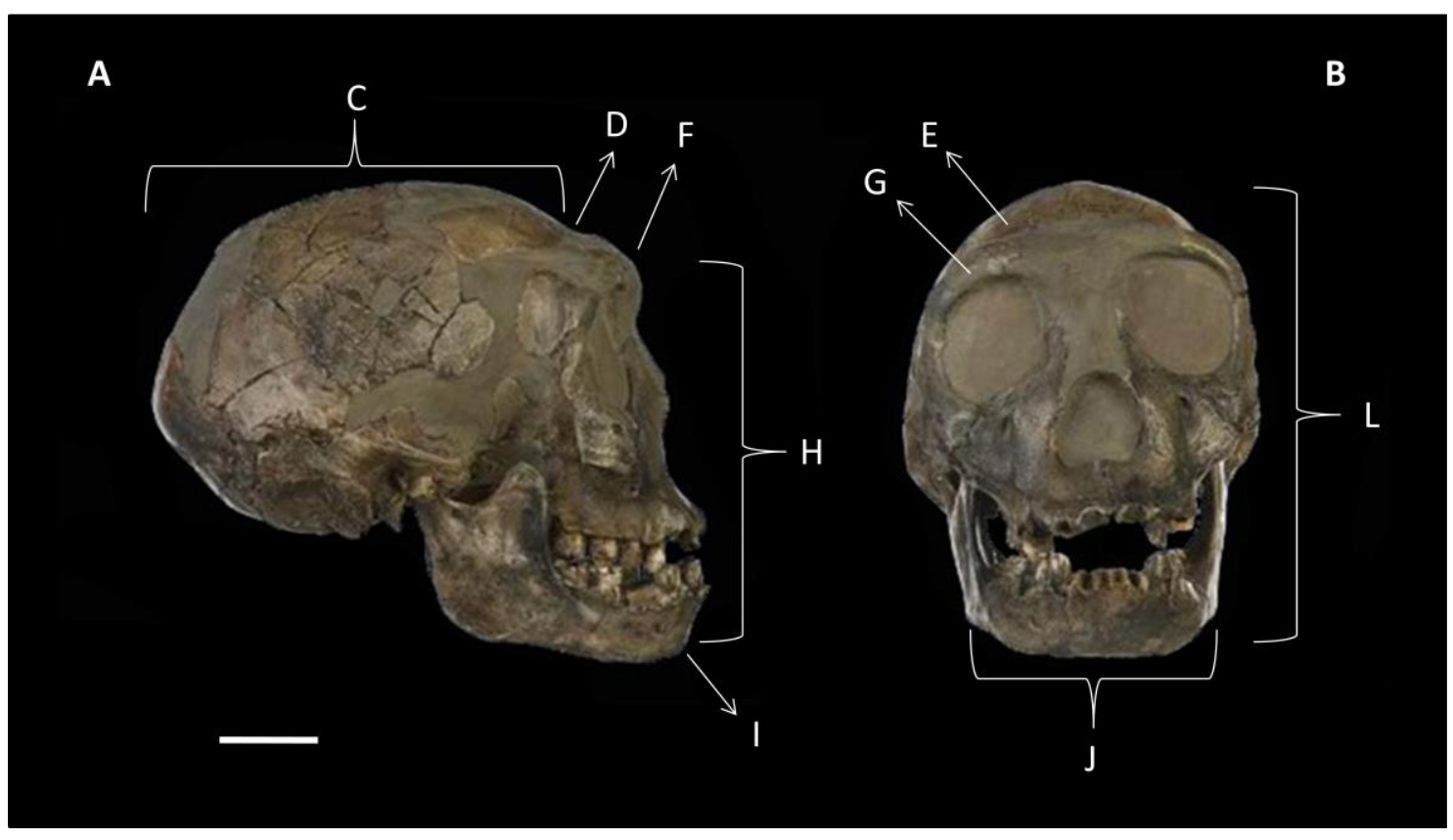

Fig. 4. Side (A) and front (B) view of the skull of Homo erectus. C: Elongated skull backwards; D, E: Retreated frontal region; F, G: Prominent supraorbital arcade; H: Considerably prominent face; I, J: Absence of mental protuberance and; L: Low braincase. Scale Bar $5 \mathrm{~cm}$. Modified from < http://www.nhm.ac.uk/nature-online/life/human-origins/modern-human-evolution/3d-hominid-skulls>. 
Tab. 1: Answers to the query: "What are the differences of sinuous in lateral profile of each skull?". The number and percentage of answers included at the end of each response indicates the absolute and relative abundance of students who agreed with this response.

\begin{tabular}{|c|c|c|}
\hline Central Idea & $3 \mathrm{D}$ & $2 \mathrm{D}$ \\
\hline $\begin{array}{l}\text { CSD1 - Homo sapiens } \\
\text { neanderthalensis is similar to } \\
\text { Homo sapiens sapiens. }\end{array}$ & $\begin{array}{l}\text { "The face of the skull of Neanderthal (...) } \\
\text { is developed and presents sinuous (...) } \\
\text { viewed from side. (...). They are similar to } \\
\text { the face and skull (...) of Homo sapiens } \\
\text { sapiens (...) (6), } 40 \%\end{array}$ & $\begin{array}{l}\text { "Observing the side of } H \text {. sapiens } \\
\text { neanderthalensis skull (...): its size is } \\
\text { normal, his face is sinuous (...) and his } \\
\text { jaw is elongated (...), similar to our". } \\
(4), 19 \% \text {. }\end{array}$ \\
\hline $\begin{array}{l}\text { CSD2 - Homo sapiens } \\
\text { neanderthalensis is different } \\
\text { from Homo erectus. }\end{array}$ & $\begin{array}{l}\text { "The skull of Homo erectus has his face } \\
\text { and (...) jaw much more prominent and } \\
\text { less sinuous (...). The Neanderthal skull } \\
\text { has a slightly prominent jaw and much } \\
\text { larger skull". (14), } 93 \%\end{array}$ & $\begin{array}{l}\text { "Observing the side of both skulls } \\
\text { (...), The Neanderthal man has skull } \\
\text { with side features (...), your face is } \\
\text { more sinuous, with finer details. The } \\
\text { skull of } H \text {. erectus is flattened, small } \\
\text { and round". (6), } 38 \%\end{array}$ \\
\hline $\begin{array}{l}\text { CSD3 - Homo sapiens } \\
\text { neanderthalensis is different } \\
\text { from Homo erectus and } \\
\text { similar to Homo sapiens } \\
\text { sapiens. }\end{array}$ & $\begin{array}{l}\text { "The skull of Neanderthals is different } \\
\text { from } H \text {. erectus and much more similar } \\
\text { and (...) almost equal to our skull (...)". (5), } \\
33 \%\end{array}$ & $\begin{array}{l}\text { "The Neanderthal is different than } H \text {. } \\
\text { erectus, but has a skull much more } \\
\text { similar to our one". (1), } 6 \%\end{array}$ \\
\hline
\end{tabular}

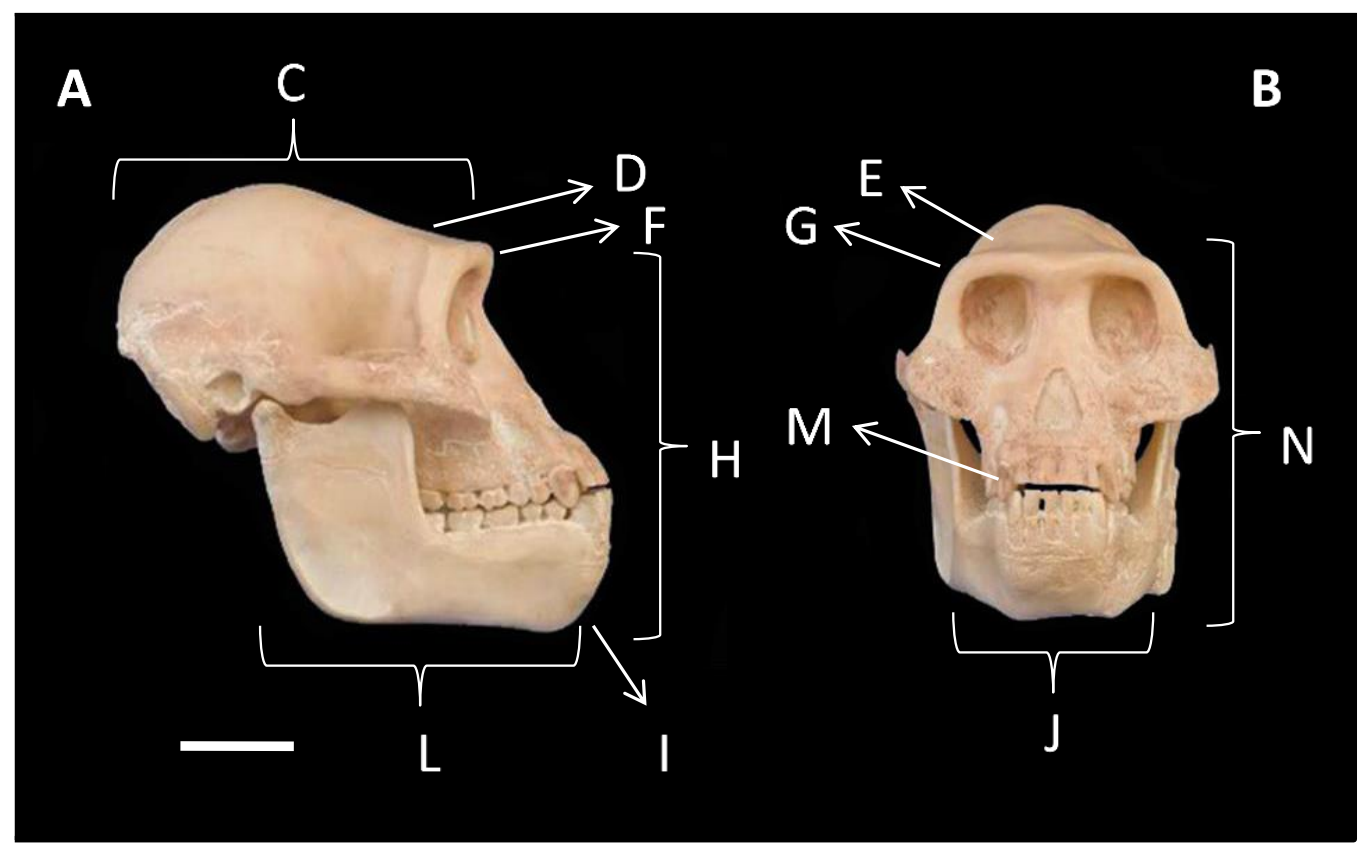

Fig. 5. Side (A) and front (B) view of the skull of Australopithecus afarensis. C: Elongated skull backwards; D, E: Retreated frontal region; F, G: Prominent supraorbital arcade; H: Significantly prominent face and presence of canines; I, J: Absence of mental protuberance; L: High and long length jaw; M: Presence of canines and; N: low braincase. Scale Bar $5 \mathrm{~cm}$. Modified from <http://www.nhm.ac.uk/natureonline/life/human-origins/modern-human-evolution/3d-hominid-skulls>. 


\subsection{Results presented in Table 2}

Table 2 records the answers to the question "What kind of influence has developed this difference?". In both teaching resources, students perceived more intrinsic influences (increasing of cranium) in relation to extrinsic influences (food and environment). In CSD1 (Tab. 2), students considered that the difference between the faces of $H$. erectus and $H$. sapiens neanderthalensis skulls was caused by the volume of the cranium. In CSD2 (Tab. 2), students considered that this influence was due to external factors (environmental and food). In CSD3 (Tab. 2), students considered that this influence should have been caused by both internal factors, but also by external factors, such as environment, food and skull size. This last discourse only was made by students who developed the activity with the 3D educational resource.

\subsection{Results presented in Table 3}

Table 3 shows the responses to the question: "Do you think that Homo sapiens neanderthalensis could talk? Explain your answer". This table shows that the students answered affirmatively to the hypothesis that $H$. sapiens neanderthalensis could speak.

In CSD1 (Tab. 3), all students, with the 3D educational resource, shared the observation of the similarity of $H$. sapiens neanderthalensis and the $H$. sapiens sapiens skulls. In CSD 2 (Tab. 3), most students using the $2 \mathrm{D}$ teaching resource, supported the hypothesis what $H$. sapiens neanderthalensis could not speak since the tongue muscle was little evolved. But they shared the idea that the evolution could determine structural improvements arguing that "Yes, because he has the tongue muscle little evolved". This suggests that the $2 \mathrm{D}$ teaching resource may have contributed to this misunderstanding, due to the absence of a more suitable analysis of this evolutionary aspect.

In CSD3 (Tab. 3), few students considered the similarity between $H$. sapiens neanderthalensis and $H$. sapiens sapiens skull.

Tab. 2. Answers to the query: "What kind of influences has developed these differences?". The number and percentage indicated at the end of each answer indicates the absolute and relative abundance of students who agreed with the given response.

\begin{tabular}{|c|c|c|}
\hline Central Idea & $3 \mathrm{D}$ & $2 \mathrm{D}$ \\
\hline CSD 1. intrinsic & $\begin{array}{l}\text { "This difference is due to the size of the } \\
\text { skull of the Neanderthal, which had the } \\
\text { largest brain (...), having greater } \\
\text { intelligence. He could probably cook } \\
\text { which could helped him in cold } \\
\text { environments". (15), } 100 \%\end{array}$ & $\begin{array}{l}\text { "H. sapiens neanderthalensis was } \\
\text { cleverer". (6), } 38 \%\end{array}$ \\
\hline CSD2. extrinsic & $\begin{array}{l}\text { "This difference is due to food and the } \\
\text { environment (...) where Homo erectus is } \\
\text { more adapted to eat hard food. The } \\
\text { Neanderthal lives in colder environments } \\
\text { and eat softer food". (13) } 86 \%\end{array}$ & $\begin{array}{l}\text { "This difference is due to the region } \\
\text { where they live and what they eat". } \\
\text { (4), } 25 \%\end{array}$ \\
\hline $\begin{array}{l}\text { CSD3. intrinsic and } \\
\text { extrinsic }\end{array}$ & $(13), 86 \%$ & $(0), 0 \%$ \\
\hline
\end{tabular}




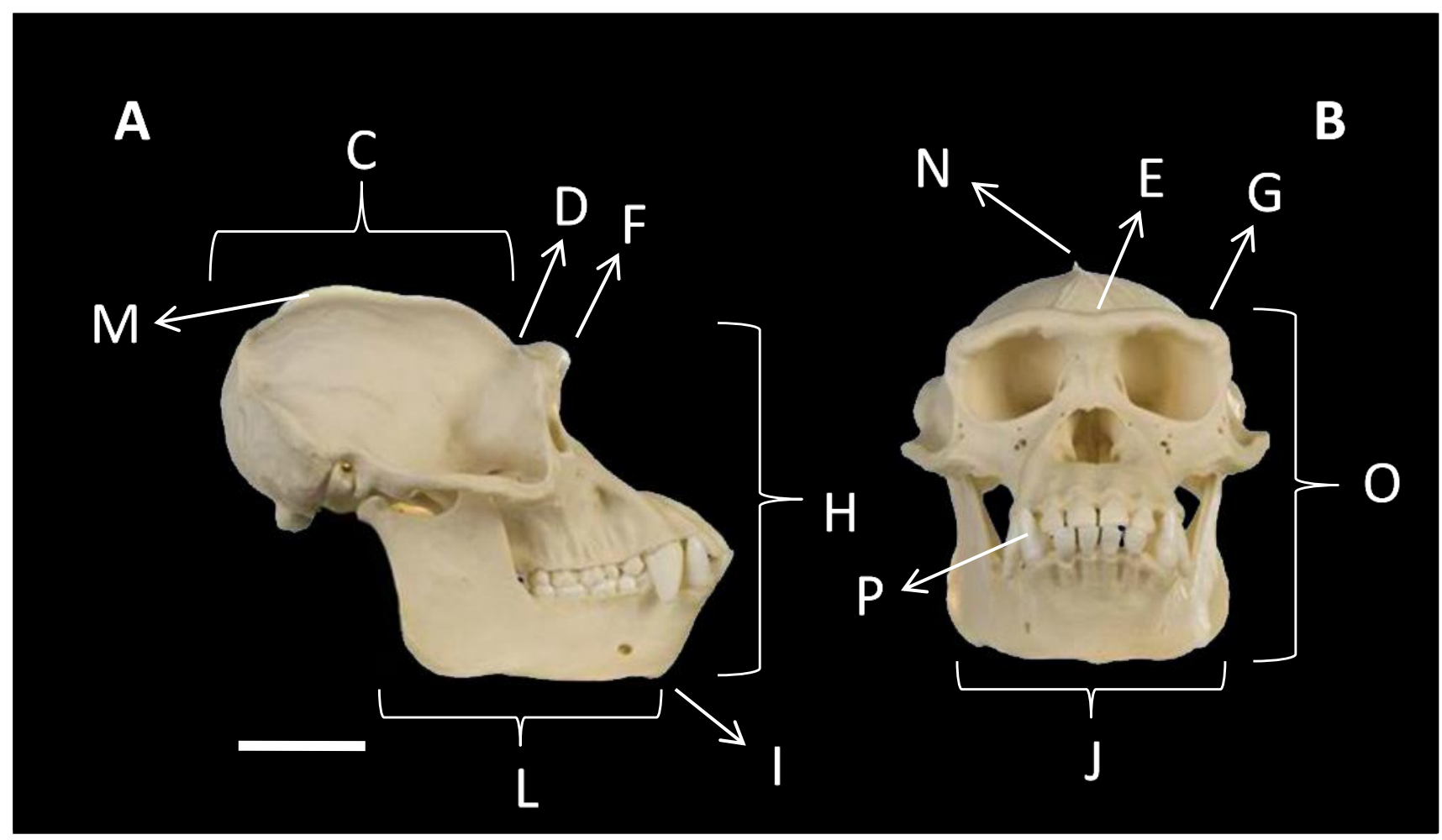

Fig. 6. Side (A) and front (B) view of the skull of Pan troglotydis. C: Elongated skull backwards; D, E: Retreated frontal region; F, G: Prominent supraorbital arcade; H: face very prominent with the presence of canines; I, J: Absence of mental protuberance; L: Prominent bit and long jaw; M, N: Presence of sagittal crest; O: Low braincase and, P: Presence of large canines. Scale Bar $5 \mathrm{~cm}$. Modified from <http://www.nhm.ac.uk/nature-online/life/human-origins/modern-human-evolution/3d-hominid-skulls>.

\subsection{Results presented in Table 4}

The Table 4 summarizes the hypotheses built by students to the question "Do you think that Homo sapiens neanderthalensis could talk? Explain your answer". This table shows that the number of hypotheses formulated by students involved in the activity with the 3D teaching resource was higher when compared to the activity with $2 \mathrm{D}$ teaching resource. The first group also presented a greater diversity of hypotheses.

In the $3 \mathrm{D}$ activity, the assumptions made by the students were more related to similarities between the skulls, the shape of the skull, the brain dimension and the ability to think. Whereas in the activity with $2 \mathrm{D}$ teaching tool, students formulated hypotheses more related to the muscles, the brain dimension, the ability to think, the jaw similarity and the shape of the jaw. Results presented in Table 4 evidence that there was a difference both in the quality and quantity of hypotheses formulated by both groups.

\section{Discussion}

The results presented in Tables 1 and 2, evidence that for all CSD, the students who analyzed 3D educational resource responded more appropriately than students that used the $2 \mathrm{D}$ teaching resource.

In these tables, most of the students who analyzed the $3 \mathrm{D}$ teaching resource apprehended the differences between the analyzed skulls, due to the possibility of handling the 3D model of the skull. In the case of the group with $2 \mathrm{D}$ teaching resource, only a few students were able to see the differences between the analyzed skulls.

The students with the 3D teaching resource were able to associate and link several analysis perspectives. This result is a consequence of a better observation and perception of the studied structures. So the students were able to articulate and formulate more plausible hypotheses.

In Table 3, we note that all students in both activities, realized that the skull of $H$. sapiens neanderthalensis was similar to that of $H$. sapiens sapiens. 
However, in the activity with 2D teaching resource, they included the argument that "the language was less evolved". Thus they presented a misconception: "as he was an older hominid, he had a less developed language". This view may have been attributed to the fact that hominids had less developed features. These results suggests that the 2D didactic recourse did not allow a correct analysis due to the characteristics of the study material. Note that the responses of the $2 \mathrm{D}$ team do not total $100 \%$.

In Table 4, it is noted that students with 3D teaching recourse were able to formulate more hypotheses than the students with $2 \mathrm{D}$ teaching resource. These results suggest that the 3D models provide a more accurate perception, a better analysis of structures which allowed improved hypothesizing.

Tab. 3. Answers to the query: "Do you think that Homo sapiens neanderthalensis could talk? Explain your answer". The number and percentage included at the end of each response indicates the absolute and relative abundance of students who agreed with this response.

\begin{tabular}{|c|c|c|}
\hline Central Idea & $3 \mathrm{D}$ & $2 \mathrm{D}$ \\
\hline $\begin{array}{l}\text { CSD1. Yes, they had similar } \\
\text { braincase. }\end{array}$ & $\begin{array}{l}\text { "Yes, they have the large braincase like } \\
\text { ours (...). Very similar to ours. Thus the } \\
\text { brain was greater". (15) } 100 \%\end{array}$ & $0(0 \%)$ \\
\hline $\begin{array}{l}\text { CSD2. Yes, because the tongue } \\
\text { muscle was little evolved. }\end{array}$ & $0(0 \%)$ & $\begin{array}{l}\text { "Yes, because he has the tongue } \\
\text { muscle little evolved". (10) } 62 \%\end{array}$ \\
\hline $\begin{array}{l}\text { CSD3. Yes, they had the skull } \\
\text { similar to ours. }\end{array}$ & $0\left(0^{\circ} \%\right)$ & $\begin{array}{l}\text { "Yes, they have similar mandible, jaw } \\
\text { and brain to H. sapiens". (3) } 19 \%\end{array}$ \\
\hline
\end{tabular}

Tab. 4. Hypotheses built by students to the question "Do you think that Homo sapiens neanderthalensis could talk? Explain your answer". The number and percentage included at the end of each response indicates the absolute and relative abundance of students who agreed with this response.

\begin{tabular}{|l|c|c|}
\hline \multicolumn{1}{|c|}{ Hypotheses } & 3D & 2D \\
\hline $\begin{array}{l}\text { Because of the shape of the } \\
\text { braincase. }\end{array}$ & $(10) 66 \%$ & 0 \\
\hline $\begin{array}{l}\text { By having a larger brain capacity to } \\
\text { think. }\end{array}$ & (4) $26 \%$ & 0 \\
\hline $\begin{array}{l}\text { By owning a similar skull to Homo } \\
\text { sapiens sapiens. }\end{array}$ & $(6) 40 \%$ & $(4) 25 \%$ \\
\hline $\begin{array}{l}\text { Because they have developed } \\
\text { muscle for this. }\end{array}$ & 0 & $(1) 6 \%$ \\
\hline $\begin{array}{l}\text { Because they have larger brains, } \\
\text { ability to think. }\end{array}$ & 0 & $(1) 6 \%$ \\
\hline $\begin{array}{l}\text { By owning a similar jaw to Homo } \\
\text { sapiens sapiens. }\end{array}$ & 0 & $(2) 12 \%$ \\
\hline $\begin{array}{l}\text { By the form of jaw. } \\
\text { Total }\end{array}$ & $\mathbf{2 0}$ & $\mathbf{8}$ \\
\hline
\end{tabular}


The CSD analysis was a usefull thecnique to evaluate which of teaching resources (2D and 3D) have generated greater motivation and learning opportunity. According to Cavicchia (2010), motivation also improve the affective relatioshionships and hence the cognitive process.

The CSD analysis showed that students who participated in the activity with 3D teaching resource had better results, formulated more hypotheses and shared more than a discourse. They also were able to build a new knowledge without incorrect concepts about human evolution through intense interaction with the team members and careful examination of the fossils into three-dimensional models.

Students who participated in the activity with $2 \mathrm{D}$ teaching resource were able to make observations, formulate hypotheses and construct new knowledge through the interaction between students and monitors, but some concepts about human evolution remained equivocal. "Yes, because he had the tongue muscle little evolved" - this sentence summarizes the responses given by most students involved in the activity with the 2D teaching resource.

According to Vygotsky (1987), when students continue with misconceptions, that is, when the signs are interpreted wrongly, we can deduce that the interaction between the students and professor was not enough for the formation and construction of new knowledge. This small interaction may have influenced the formation of incorrect concepts.

For Gagné (1980), behavioral change is always persistent when the new knowledge is inserted and the individual interacts with it, showing satisfaction and acceptance. For this author, the student reacts to stimulation and motivation, changing their behavior.

According to Comenius (1999), when there are the interaction of more than one sense, for example, viewing and handling (in this case, the virtual handling) the acquisition of knowledge knowledge is improved. In the case of the students who use the 2D models, the misconceptions continued which indicate that the motivation was not enough and the interaction between the students and the didactic recourse were not adequate.

\section{Conclusion}

The 3D teaching resource motivated much more the students and helped them to interact, increasing their social, emotional and cognitive relationships. According to the results of this work, the 3D teaching tool allowed for greater ease of observation, perception, comparison and analysis of the anatomical structures of the skull in relation to $2 \mathrm{D}$ teaching resource.
Thus, students of both activities, somehow interacted with each other, interpreting signs, forming and building concepts based on these signs. In the activity with 3D educational models where student formulated questions and doubts, the group interacted much more, answering to such questions and doubts. That is, social interaction helped in the construction and acquisition of new knowledge.

For Vygotsky (1987) the signs (in this case, the new knowledge) are mediated by the relationships, in which all individuals are building their own concepts, and so these are influenced by the social interactions.

The student's behavior in the activity using the 3D teaching recourse revealed that despite some emerging questions or conflicts between science and religion, the students learned and argue coherently about the scientific thinking on human evolution. In the $2 \mathrm{D}$ activity, some students were inattentive or uninterested about the subject.

The quality of the answers expressed by the students involved in the activity using the $3 \mathrm{D}$ teaching recourse are linked with their enthusiasm and understanding the content. According to Martins et al. (2005), the interest by the scientific content is facilitated by the efficiency of the teaching resource and its effectiveness as a learning motivation tool. The emotional and motivational processes are essential for an activity that is full of signs, in which the student has the opportunity to observe, analyze and formulate their hypotheses (Flavell et al., 1999; Moreira, 1999; Sternberg 2000; Uller, 2007).

The use of an effective teaching tool can help the students to understand the new concepts that are being taught. So the choice of the resource and convenient planning of the activity is of paramount importance.

According to Bento and Gonçalves (2011), the use of 3D models is more motivating than the $2 \mathrm{D}$ images. Teaching resources with 3D models provide a better analysis of biological structures than 2D models. Thus the use of 3D models can be important as a didactic recourse for the paleontology teaching.

This research evidences the importance of the quality of educational teaching resources. They can facilitate the process of teaching-learning.

The 3D teaching tool used in this work, is easily accessible, and promotes more interaction and better learning for teaching subjects related to human evolution than 2D pictures. 


\section{Acknowledgments}

The authors would like to thank the reviewers of Journal of Sedimentary Environments for their collaboration in the improvement of this work. The authors also would like to thank CEMA and Geodiversity Museum for hosting the activities of this work. The authors would like to thank the National Research Ethics Commission (CONEP) for give permition to realize this research

\section{References}

Ayala, F.J., 2007. Darwin's greatest discovery: design without designer. Proceedings of the National Academy of Sciences 104, 8567-8573. http://www.pnas.org/cgi/doi/10.1073/pnas.0701072104

Bento, J.J.F., Gonçalves, V.B., 2011. Ambientes 3D no processo de ensino e aprendizagem. Eduser: Revista de Educação 3, 45 $-58$.

Brasil, 2002. Orientações Complementares aos Parâmetros Curriculares Nacionais Ensino Médio - Ciências da Natureza, Matemática e suas Tecnologias. Secretaria da Educação Básica. Ministério da Educação e Cultura/SEB, Brasília 144 pp.

Brasil. 2000. Parâmetros Curriculares Nacionais Ensino Médio Parte III - Ciências da Natureza, Matemática e suas Tecnologias. Secretaria da Educação Básica. Secretaria da Educação Básica. Brasília Ministério da Educação e Cultura/SEB. 58 pp.

Castro, N.B.L., Augusto, T.G.S., 2009. Análise dos Trabalhos sobre o Ensino de Evolução Biológica Publicados nos Anais do VI ENPEC. In: VII Encontro Nacional de Pesquisa em Educação em Ciências, 1 - 12.

Cavicchia, D.C.O, 2010. Desenvolvimento da Criança nos Primeiros Anos de Vida. Psicologia do Desenvolvimento. UNESP: Júlio de Mesquita Filho. UNIVESP. 1 - 15.

Comenius, J.A., 1999. Didática Magna. São Paulo. Martins Fontes, $432 \mathrm{pp}$.

Diniz, M.T.M., Vasconcelos, F.P., Maia-Vasconcelos, S.M., Rocha, G.C., 2011. Utilização de entrevistas semi-estruturadas na gestão integrada de zonas costeiras: o Discurso do Sujeito Coletivo como Técnica Auxiliar. Scientia Plena 7, 1-8.

Flavell, J.H., Miller, P.H., Miller, S.A., 1999. Desenvolvimento Cognitivo. 3. ed. Porto Alegre, Artmed, 222 pp.

Gagné, R.M., 1980. Princípios Essenciais da Aprendizagem para o Ensino. In: Ed Globo, Porto Alegre. Trad. Baquero, R.V.A., 175 pp.

Godim, S.M.G., Fischer, T., 2009. O Discurso. A Análise de Discurso e a Metodologia do Discurso do Sujeito Coletivo na Gestão Intercultural. Caderno Gestão Social, Revista do Centro Interdisciplinar de Desenvolvimento e Gestão Social 2, 09-26.

Jodelet, D., 1990. Represéntation sociale: phenomèmes, concept et theorie. In: Psycologie sociale, Paris, PUF, $201 \mathrm{pp}$.

Lefèvre, F., Lefèvre, A.M.C., 2003. Princípios básicos e conceitos fundamentais do Discurso do Sujeito Coletivo. In: Lefèvre, F., Lefèvre A.M.C. (orgs.), O Discurso do Sujeito Coletivo: um novo enfoque em pesquisa qualitativa (desdobramentos), Caxias do Sul, Editora da Universidade de Caxias do Sul, 13-57.
Martins, I., Gouvêa, G., Piccinini, C., 2005. Aprendendo com Imagens. Revista Ciência e Cultura São Paulo 57, 38-40.

Moreira, M. A. 1999. Teorias de Aprendizagem. Editora Pedagógica e Universitária, 198 pp.

Mottola, N.A., 2012. Importância do Darwinismo no Ensino de Evolução. Universidade Estadual Paulista - Rio Claro. Biosferas.

Moura, J.C.S., Silva-Santana, C.C., 2012. A evolução humana sob a ótica do Professor do Ensino Médio. Feira de Santana. Revista Metáfora Educacional 13, 93-108.

Oliveira, G.S., Bizzo, N., 2011. Aceitação da evolução biológica: atitudes de estudantes do ensino médio de duas regiões brasileiras. Revista Brasileira de Pesquisa em Educação em Ciências 11, 57-79.

Oliveira, G.S., Pagan, A.A., Bizzo, N., 2011. Aceitação e Rejeição das Teorias Evolutivas entre Estudantes. Biosfera. Artigos: evolução. Universidade Estadual Paulista - Rio Claro.

Pazza, R., Penteado, P.R., Kavalco, K.F., 2010. Misconceptions about Evolution in Brazilian Freshmen Students. Evolution, Education and Outreach 3, 107-113.

Penny, D., Poole, A. 1999. The Nature of the last Universal Common Ancestor. Current Opinion in Genetics \& Development. 9, 672-677.

Rio de Janeiro, 2012. Currículo Mínimo, - Ciências e Biologia. Secretaria de Estado de Educação - SEEDUC. Governo do Estado do Rio de Janeiro. 16 pp.

Roberto, E.C., Bonotto, D.M.B., 2012. Ensino de Evolução: Concepções e Conflitos em Sala de Aula. Universidade Estadual Paulista - Rio Claro. Biosfera,

Santos, E.T., Mafalda, R., Kawano, A., Cheng, L., Petreche, J.R.D., Leite, B.C.C., Ferreira, S.L., Cardoso, L.R.A., 2003. Da geometria cotada ao modelamento $3 \mathrm{~d}$ : projeto didático. In: $16^{\circ}$ simpósio nacional de geometria descritiva e desenho técnico, $\mathrm{V}$ International Conference on Graphics Engineering for Arts and Design. Santa Cruz do Sul. Anais, 8-11.

Santos, G.T., Dias, J.M.B., 2015. Teoria das representações sociais: uma abordagem sociopsicológica. PRACS: Revista Eletrônica de Humanidades do Curso de Ciências Sociais da Universidade Federal do Amapá, 8, 173-187.

Seabra, T.R., Santos, T.E., 2004. Proposta de desenvolvimento da habilidade de visualização espacial através de sistemas estereoscópicos. In $4^{\circ}$ Congreso Nacional y 1 ro. Internacional. Rosário. Argentina, 1-10 pp.

Sêga, R.A.O., 2000. Conceito de representação social nas obras de Denise Jodelet e Serge Moscovici. Anos 90, Porto Alegre 13, 128-133.

Silva, C.S.F, Lavagnini, T.C, Oliveira, R.R., 2009. “O Homem Veio do Macaco?" O que pensam os alunos da $3^{a}$ Série do Ensino Médio sobre a Evolução Humana. Enseñanza de las Ciencias, Numero Extra, VIII Congresso Internacional sobre Investigacíon en Didáctica de las Ciencias, Barcelona 1454 1457 pp. 
Sternberg, R.J., 2000. Psicologia Cognitiva. Porto Alegre: Artes Médicas Sul, 21-41.

Sutton, M. D., Briggs, D.E.G., Siveter, D. J., 2001. Methodologies for the Visualization and Reconstruction of Three-dimensional Fossils from the Silurian Herefordshire Lagerstätte. Palaeontologia Electronica, 4, 1-17.

Tidon, R., Vieira, E., 2009. O Ensino da Evolução Biológica: Um Desafio para o Século XXI. ComCiência, 107, 0-0.

Toti, F.A., Martins, I.L., Silva, A.D., 2008. A integração da computação gráfica no ensino-aprendizagem do desenho técnico. Congressos Brasileiro de Educação em Engenharia, 19 .

Uller, W., 2007. Afetividade e Cognição. Material de apoio apresentado como fonte de pesquisa e material didático.
Programa de Desenvolvimento Educacional. Universidade Estadual de Ponta Grossa, 1 - 51.

Vieira, V., Falcão, E.B.M., 2014. Visões sobre a teoria evolutiva: pressões institucionais religiosas e ciência. Edição Especial, Ensino, Saúde e Ambiente 7, 1-12.

Vieira, V., Falcão, E.B.M., 2012. "Eu não confio na evolução, mas no resto eu confio quase que às cegas." Evolução biológica: o limite entre ciência e crença religiosa. Ensino, Saúde e Ambiente 5, 138-148.

Vygotsky, L.S., 1987. Pensamento e Linguagem. In, Mores, R. C. (Ed). 2004. Edição eletrônica, 136pp. www.jahr.org.

Wilhite, R., 2003. Digitalizing Large Fossil Skeletal Elements for Three-Dimensional Applications. Palaeontologia Electronica $5,1-10$. 